\title{
The discovery of latent heat 250 years ago
}

\author{
STEFAN EMEIS*
}

Weilheim, Germany

(Manuscript received January 7, 2004; in revised form May 10, 2004; accepted May 10, 2004)

\begin{abstract}
The concept of latent heat plays an important role in the description of the energy balance of the Earth's atmosphere. It is a quarter of a millennium ago that J.A. DELUC began his experiments on melting ice. He discovered that during the melting some heat is concealed in the water without affecting the thermometer. Some years later J. BLACK coined the term 'latent heat' for this phenomenon. Thirty-two years later DELUC discussed with J. WATT the question of who should be credited for this discovery. Excerpts from a book by DELUC, from the manuscripts of BLACK's lectures and from a letter by WATT illustrate the topic. WATT's letter and DELUC's reply to it are an early example of what is found today in the 'Letters to the Editor' section of scientific journals.
\end{abstract}

\section{Zusammenfassung}

Das Konzept der latenten Wärme ist unabdingbar bei der Beschreibung der Energiekreisläufe in der Erdatmosphäre. Es ist jetzt ein Vierteljahrtausend her, dass J.A. DELUC mit seinen ersten Versuchen zum Schmelzen von Eis begann. Er entdeckte dabei, dass während des Schmelzens ein Teil der zugeführten Wärme vom sich bildenden Wasser verschluckt wird, ohne das Thermometer zu beeinflussen. Einige Jahre später prägte J. BLACK den Begriff 'latente Wärme' für dieses Phänomen. 32 Jahre später diskutierten DELUC und J. WATT darüber, wem die Entdeckung der latenten Wärme zuzuschreiben sei. Auszüge aus einem Buch von DELUC, aus BLACKs Vorlesungsmanuskripten und aus einem Brief von WATT an DELUC illustrieren diesen Aspekt der Wissenschaftsgeschichte. Der Briefwechsel zwischen WATT und DELUC ist ein frühes Beispiel für das, was heute in der Rubrik "Briefe an den Herausgeber" in wissenschaftlichen Zeitschriften gefunden wird.

\section{Introduction}

Latent heat plays a decisive role in the global energy balance of our planet. About $80 \%$ of the radiative energy gain of the Earth's surface is transported away again by the processes of evaporation at the ground and condensation aloft. Each year $4.9 \times 10^{17} \mathrm{~kg}$ of water evaporate from the soils and oceans and return as rain or snow (this corresponds to $957 \mathrm{~mm} / \mathrm{a}$, RUdOLF and RUBEL, 2004). Annually about $1.2 \times 10^{24} \mathrm{~J}$ of energy are transported vertically into the atmosphere in this way. Without this vertical energy transfer the mechanisms of tropical storms and hurricanes could not be explained. Thus, the concept of latent energy is crucial for the understanding of the global energy balance as well as for the working principles of major atmospheric disturbances. This year, 2004, marks a quarter of a millennium since this form of energy was discovered.

In ancient Greece there was some understanding of the vertical water circulation driven by evaporation and condensation, with the sun as the primary force. But there was no suggestion of heat transport being connected to this process. The quantitative measurement of heat flow requires the measurement of the temperature. Thus detection of the heat amount necessary to,

\footnotetext{
${ }^{*}$ Corresponding author: Stefan Emeis, Bärenmühlweg 64, 82362 Weilheim, Germany, e-mail: stefan.emeis@imk.fzk.de
}

for example, evaporate water was not possible prior to the existence of the means to measure temperature. The main development of thermometers took place in the first half of the 18th century. In that period the production of these instruments was standardised (see e.g. RÉAumur, 1730) and Anders Celsius (1701-1744), Daniel Gabriel FAHRENHEIT (1686-1736), and Réné Antoine Ferchault, Seigneur de RÉaumur (16831757) proposed their temperature scales. Some aspects of the history of RÉAUMUR's scale has recently been described by EMEIS (2000). In the years in which the temperature scales were being finalised, it was known from experiments of Edmont HALLEY (1656-1742) and Guilleaume AMONTONS (1663-1705) (see the entry 'Wärme' in ZEDLER (1732-54)) that boiling water can only take up a fixed amount of heat. The physical law that was derived from these experiments was that substances, when they start to vapourize, have taken up the maximum heat they can.

In this note we will look at the work of two natural scientists, Jean André DELUC and Joseph BLACK who, shortly after the invention of reliable thermometers and independently of each other, made the discovery of latent heat. One of them appears nearly forgotten today; the other one is still known because he coined the words 'latent heat' for this form of energy. 


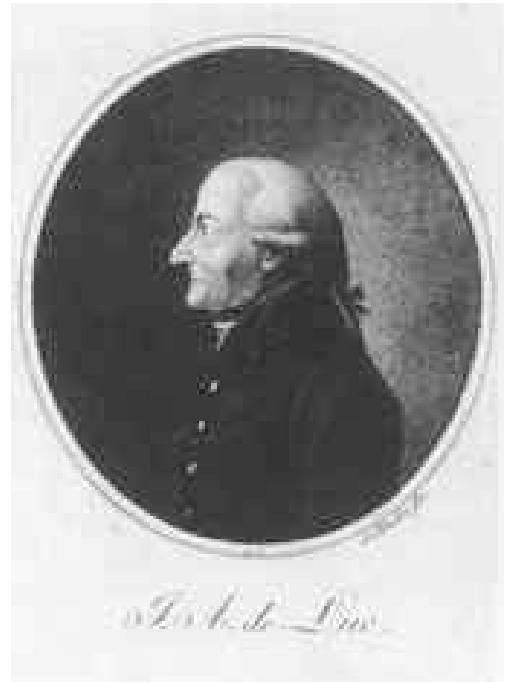

Figure 1: Jean André DeluC (1727-1817), after a drawing by GRENUs (collection Maillart).

\section{The work of Deluc}

Jean André DeluC (Fig. 1, the name is sometimes also written 'De Luc') was born in Geneva in 1727 . He became a merchant there, became bankrupt, moved to England in 1773, and was then reader to the English Queen Charlotte until he died in Windsor in 1817. During his whole life he was interested in geology and meteorology and already during his time of merchandising he made scientific excursions into the Alps. Regarding geology he was a neptunist: during his whole life he believed that all rocks on Earth were formed by sedimentation on the sea floor (with the only exception of those originating from active volcanoes). He explained the geological eras of the Earth's history being in conformity with the six days of creation described in the book Genesis in the Bible.

Also during his time as a merchant in Geneva he made his first physical experiments. During the winter of 1754/55 DELUC investigated the melting of ice and reported on these investigations in his book on the "Modifications of the atmosphere" (Fig. 2, DELUC, 1772). In a later book entitled "New ideas on meteorology", which appeared first in French in 1786, he summarised the experiments in $\S 179$ (DELUC, 1787):

I let freeze water in drinking glasses in which I had put thermometers whoses bulbs thereby were enclosed by the ice. Thereafter I brought this little apparatus to a fire. The thermometers rose until the very moment as the ice started to melt. All fire that intruded the ice thereafter ceased to have an effect on the thermometers, because it was used to make water, while at the same time the light that freed itself from the burning particles, radiated through the ice. (DELUC, 1787, p. 124).

Some pages later, in $\S 210$, DELUC noted:

$D$. Black was the first who tried to determine the heat

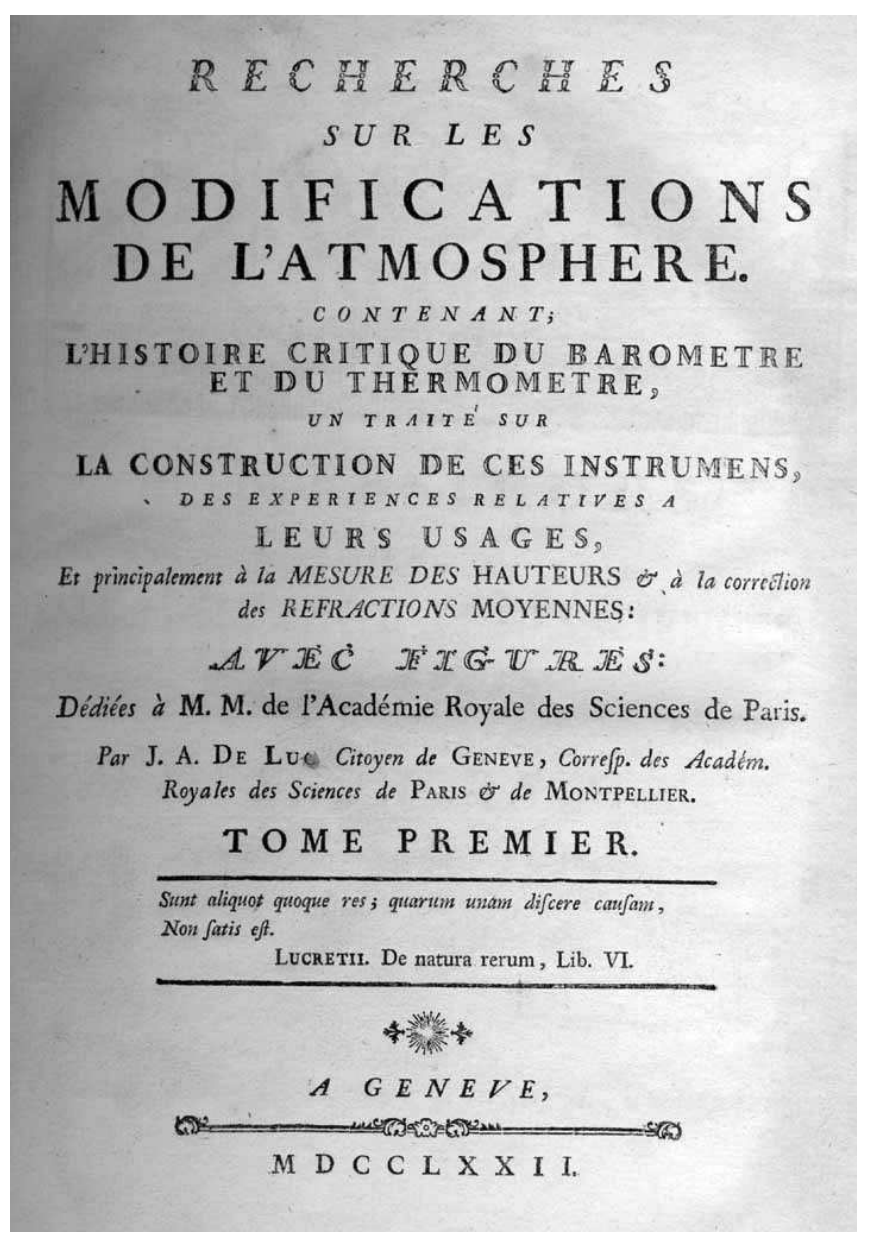

Figure 2: Title page of DELUC's first book on the "Modifications of the Atmosphere", published in Geneva in 1772. Source: web pages of the University of California in San Diego (orpheus.ucsd.edu).

which is concealed by the ice when it melts. (DELUC, 1787, p. 143).

In 1756 DELUC also conducted experiments where he observed that some heat was concealed when water evaporates and that this heat was set free again when "the water vapours decompose" again. The term "decompose' for condensation sounds strange from today's point of view. But at that time DELUC and many other scientists who followed atomistic theories (there had to be a special substance for every physical effect: the phlogiston theory belonged to this group of theories) believed that evaporation was produced by a composition of the water particles with the fire particles (the substance which contains the heat). Some natural philosophers even described the vapourisation as a solution of the water substance in the matter of heat. Logically, condensation took place when the water particles and the fire particles separated or decomposed again.

\section{The work of Black}

Joseph BLACK (Fig. 3) was a Scottish Chemist and Professor in Glasgow and Edinburgh. He was born in 


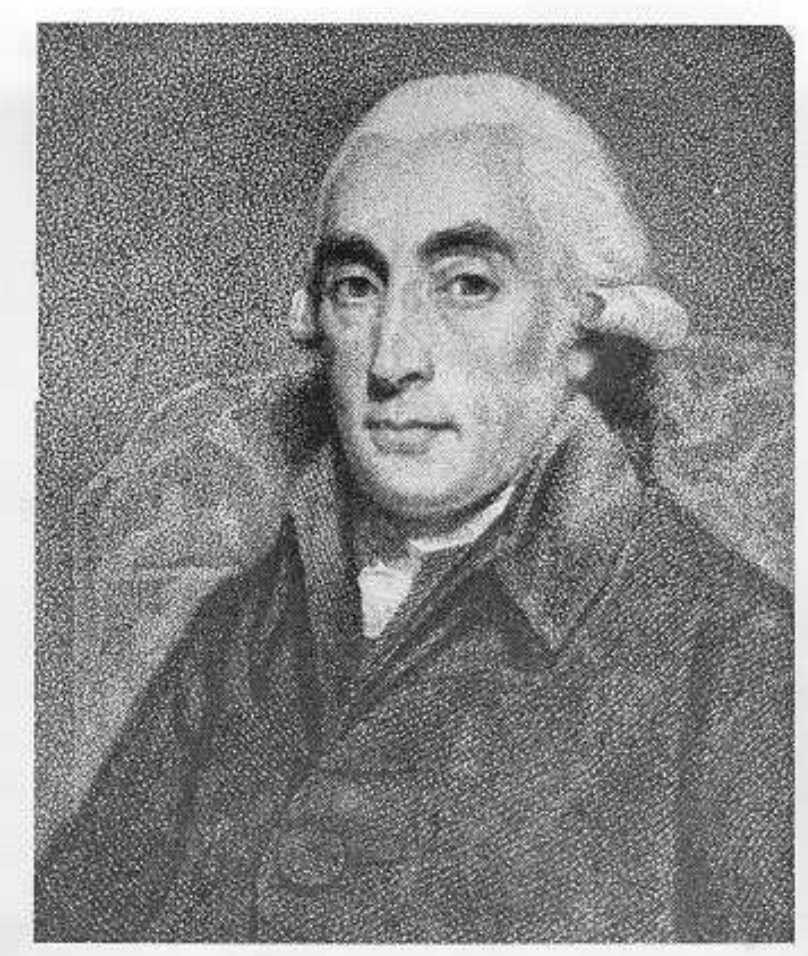

Figure 3: Joseph BLACK (1728-1799). Source: web pages of the University of Glasgow (www.chem.gla.ac.uk).

1728 in Bordeaux as a son of an Irish merchant from Belfast who was of Scottish origin. At the age of 12 he moved to relatives in Belfast, started to study Latin and Greek there and later medicine at Glasgow University. In 1750 he moved to Edinburgh and in 1754 he presented there his inaugural dissertation. In 1757 he began his lectures at the University of Glasgow. The great chemist Justus von LIEBIG (1803-1873) later rated BLACK's chemical investigations as fundamental for the antiphlogistic chemistry. To him the experiments of LAVOISIER (1743-1794) were only an imitation of BLACK's experiments with limestone and fixed air, a gas now known as carbon dioxide (LIEBIG, 1865: p. 40/41). BLACK died in Edinburgh in 1799. His lectures have been published from his manuscripts by John RoBINSON in 1803 (MAGIE, 1935). The prevailing view on the phenomenon of melting at that time was characterised by BLACK in saying:

Fluidity was universally considered as produced by a small addition to the quantity of heat which a body contains, when it is once heated up to its melting point; ... that a solid body, when it is changed into a fluid, receives no greater addition to the heat within it than what is measured by the elevation of temperature ...

BLACK soon found reasons to object to this theory. Snow was only melting slowly in spring and ice could be kept until summer in 'ice-houses'. He argued that if snow and ice in cold countries melted as suddenly as they had to do if the above theory would be correct, then enormous floods would sweep away everything in these countries. He came to the conclusion:

It is, therefore, evident, that the melting ice receives heat very fast, but the only effect of this heat is to change it into water, which is not in the least sensibly warmer than the ice was before. ... A great quantity, therefore, of the heat or of the matter of heat, which enters into the melting ice, produces no other effect but to give it fluidity, without augmenting its sensible heat; it appears to be absorbed and concealed within the water, so as not to be discoverable by the application of a thermometer.

An analogous consideration of the process of vaporisation let him finally conclude:

In both cases, considered as the cause of warmth, we do not perceive its presence: it is concealed, or latent, and I give it the name of latent heat.

It must be emphasized again that, at the time of DELUC and BLACK, heat was considered a kind of matter. Therefore, for the experimentalists of that time heat had (if it did not enter into a composition with the water particles as DeLuc believed) to change its state when entering into melting ice from its normal state into the latent state. The more astonishing was BLACK's way of describing his results: he remained unbiased and objective and merely reported pure facts without much interpreting his results in the light of one or the other of the competing theories of his time. This may be one of the main reasons that his work survived the revolution of chemistry (usually attributed to LAVOISIER) at the end of the 18th century.

\section{The debate between Watt and Deluc on the origin of the term 'latent energy'}

Joseph BLACK became a friend of James WATT (Fig. 4, 1736-1819), the famous English engineer who decisively improved the steam engine. Both were at Glasgow University. WATT had started his own experiments on steam in 1761. Until 1764 he also discovered that mixing a quantity of steam with five times its own weight of freezing water would just convert both to liquid water at the boiling point temperature. In 1764 he mentioned his findings to BLACK, who then explained to WATT his doctrine of latent heat, which he had already taught some time before this period. Obviously, both WATT and BLACK had worked for some years on the same subject at the same university without recognising it (CARNEGIE, 1905).

About 20 years later in 1786 or 1787, WATT had read that part of DELUC's book "New Ideas on Meteorology" which had already been printed and that had been sent by DELUC to several friends for comments, and he found therein in $\S 210$ the sentence on Joseph BLACK cited 
above. He wrote a letter to DELUC on this subject. In the German edition of his "New Ideas" DELUC (1787) published this letter in the appendix to the first volume and commented on it. According to Deluc, WatT wrote that he believed:

... that Dr. BLACK is the first who made a certain conception of the cause of the cold during the melting of ice, and that he has proved that the heat which seems to be lost has entered into the originating water, of which it has become a part of and that this heat has now ceased to have an effect on the thermometer: therefore he called it latent heat. ... He has taught both laws [on melting and on vaporisation] publically as a professor for chemistry since the winter 1757 to 1758 , or at the latest in the winter 1758 to 1759. I myself have learned them from him not before 1762 or 1763; nevertheless I am convinced that he had taught them at that time already for several years. (DELUC, 1787: p. 447).

We learn from WATT's letter that the dating in Carnegie's book is not completely correct. Carnegie had written that WATT had spoken to BLACK on this subject in 1764 (see above). Actually, it must have been in 1762 or 63, which is still about five years after BLACK's discoveries. WATT continued in his letter to DELUC that he did not doubt that DELUC had made his experiments. But he pointed to the difference in the work of DELUC and BLACK in writing:

You have not tried to prove this theory or to show the amount of heat which combines with the water. On the whole, the theories contained in this work [WATT addresses DELUC's book on the modifications of the atmosphere] deviate from those of Doctor Black in some essential parts; and although your discoveries have merits, these have to be attributed to both of you [Black and Deluc], because there is no hint that one of you has borrowed the ideas from the other. (DELUC 1787: p. 449).

DELUC agreed with James WATT and commented:

that what I observed in 1755 and 1756 was discovered by Dr. Black in a more direct way in 1757 or 1758 without having any knowledge of my work ... Dr. Black is the first who determined the amount of heat concealed in the water originating from the melting ice, and concealed in the vapour from the boiling water; and he was lucky to name these amounts latent heat of the water and of the vapours of boiling water. (DELUC, 1787: p. 454).

After the reply to WATT's letter DELUC added an excerpt from another letter that he had received from a friend (unfortunately he did not give the name) who had visited BLACK in Edinburgh for a longer time. In this letter it is said that Joseph BLACK gave correct credit to DELUC's work in his lectures although it had been published several years after BLACK had started to teach his own discoveries. As mentioned above, DELUC had first published his results in 1772 in his book "Modifications of the atmosphere". WATT lamented in his letter to DELUC that they in Scotland had learnt very little on DELUC's work before they got that book. He ended his letter with the remark:

I ask you to insert this letter into your appendix in order to do the Doctor and me justice. (DELUC, 1787: p. 451).

DELUC did as he was requested and he replied to WATT's letter in the following paragraphs of the appendix. Although it cannot be proven, it seems that DELUC gave a correct and complete copy of WATT's letter.

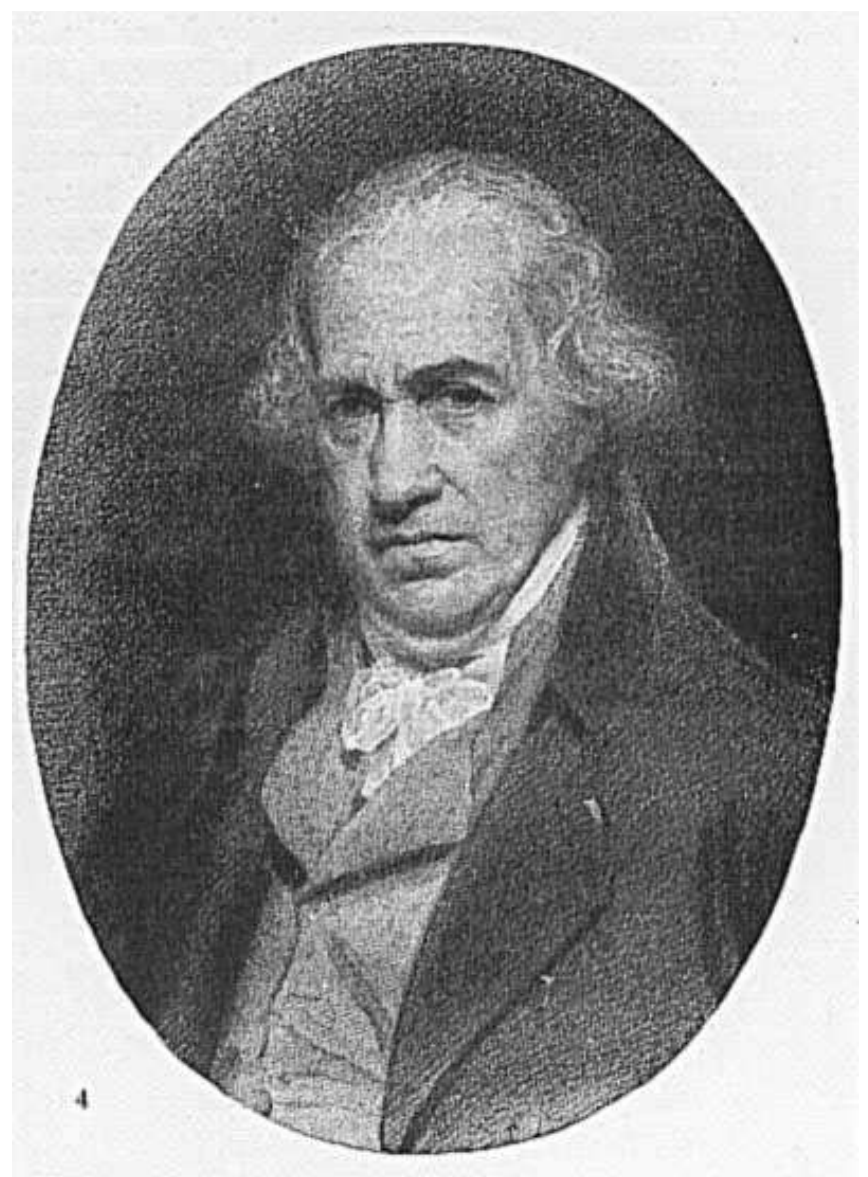

Figure 4: James WATT (1736-1819). Source: web pages of the University of Texas (www.lib.utexas.edu).

\section{Conclusions}

Scientific communication a quarter of a millennium ago was not as rapid and as frequent as today. So it could easily happen that several scientists conducted the same experiments and made similar discoveries without knowing of each other (in the case of BLACK and WATT even at the same university). In the case of latent heat DELUC started his experiments in winter 1754 in Geneva, BLACK his own experiments in 1757 in Glasgow, and WATT his in 1761, also in Glasgow. DeluC was satisfied in stating that the heat was concealed in 
the water resulting from the melting. That proved to him that the water particles had combined with those of the fire. This result was very important for him because in his framework of scientific thinking, strongly influenced by atomistic theories, every physical effect had to be explained by the action of some kind of matter. BLACK and WATT on the other hand had really investigated the amounts of heat involved in the processes of melting and vapourisation. They were interested in the actual quantity of heat, and not in the problem of whether heat is a matter or not.

DeLuC's ideas and theories did not prevail. The work of LAVOISIER and Lord RUMFORD (1753-1814) the latter discovered from the appearence of heat when drilling cannons that heat is not a matter - at the end of the 18th century proved DELUC wrong, and he was rapidly forgotten. BLACK's results confirmed WATT's own experiments on steam engines. The narrow connection of his work to WATT's very successful work on the steam engine and his discovery of fixed air (carbon dioxide) in 1757 founded BLACK's fame that lasts until today.

Regarding the possibilities and means of scientific communication, WATT's letter in the appendix of DELUC's book can be seen as an early example of what today is published in the section 'Letters to the Editor' in many scientific journals. But there was one big difference: no editor was involved. In scientific journals like the "Annalen der Physik", the publication of which started a few years later at the end of the 18th century, the editor took over the task to present letters and replies. In contrast to today's habits, the editor of the "Annalen der Physik" commented on both letters and replies in the journal. Today much of this communication is shifted to the review process and it is no longer visible for the public.

At the end of the 18th century an important task was relocated from books to the new scientific journals and remained since then a prominent feature of scientific journals, irrespective of the individual stamp of their ed- itors, to serve as a forum for the priorities of the authors and for the scrutiny and eventual refutation or acceptance of theories.

\section{Acknowledgements}

The paper benefitted from suggestions of an anonymous referee, Hans Volkert, and Michael Hantel. Stuart BRADLEY helped with the English language.

\section{References}

CArnegie, A., 1905: James Watt. - Doubleday, Page \& Company, New York. [Citations from this book were taken from the web-page: http://www.history.rochester.edu/steam/carnegie/ch3.html]

DELUC, J.A., 1772: Recherches sur les modifications de l'atmosphère. - 2 Vol., Geneva.

—, 1787: Neue Ideen über die Meteorologie. Erster Theil. Aus dem Französischen übersetzt. - Fr. Nicolai, Berlin and Stettin. 459 pp.

EMEIS, S., 2000: Who created Réaumur's thermometer scale? - Meteorol. Z. 9, 185-187.

LieBIG, J.v., 1865: Chemische Briefe. - Wohlfeile Ausgabe. C.F. Winter'sche Verlagshandlung, Leipzig and Heidelberg. $532 \mathrm{pp}$.

Magie, W.F., 1935: A Source Book in Physics. - McGraw Hill, New York. [Citations from this book were taken from the web-page:

http://webserver.lemoyne.edu/faculty/giunta/blackheat.html]

RÉAUMUR, R.A., 1730: Règles pour construire des thermomètres dont les degrés sont comparables. - Mém. Par.

Rudolf, B., F. Rubel, 2004: Global Precipitation. - In: HANTEl, M. (Ed.): Global Observed Climate. New series on Landolt-Börnstein, Numerical Data and Functional Relationships. - Springer, Berlin Heidelberg etc. Group V Vol. 6 , Ch. 11. In preparation.

ZEDLER, J.H., 1732-54: Großes vollständiges UniversalLexicon aller Wisenschaften und Künste. - Verlag von Joh. Heinr. Zedler, Halle und Leipzig. 64 volumes and 4 supplements. [Citations from this dictionnary were taken from the web-page: http://mdz.bib-bvb.de/digbib/lexika/zedler] 